\title{
Diatom of the Bacillariophyceae Class in Thermophilic Microbial Mats Present in Sulphurous Hot Springs and their Possible Biotechnological Application
}

\author{
María Jesús Puy-Alquiza ${ }^{1, *}$, Berenice Noriega Luna², Raúl Miranda-Aviles ${ }^{1}$, Ma. Mercedes Salazar \\ Hernández ${ }^{1}$ and Gilberto Carreño Aguilera ${ }^{3}$ \\ 'Departamento de Minas, Metalurgia y Geología, 2Departamento de Ingeniería Civil, ${ }^{3}$ Departamento de Geomática e \\ Hidráulica, División de Ingenierías, Universidad de Guanajuato, Campus Guanajuato, México.
}

\author{
ARTICLE INFO \\ Article Type: Research Article \\ Keywords: \\ Mexico \\ Diatoms \\ Guanajuato, \\ Applications \\ Sulphurous hot springs \\ Bacillariophyceae class \\ Thermophilic microbial mats \\ Timeline: \\ Received: November 15, 2021 \\ Accepted: December 17, 2021 \\ Published: December 29, 2021
}

Citation: Puy-Alquiza MJ, Luna BN, Miranda-Aviles R, Hernández MMS, Aguilera GC. Diatom of the Bacillariophyceae Class in Thermophilic Microbial Mats Present in Sulphurous Hot Springs and their Possible Biotechnological Application. Glob J Earth Sci Eng. 2021; 8: 80-96.

DOl: https://doi.org/10.15377/2409-5710.2021.08.7

*Corresponding Author

Email: yosune.puy155@gmail.com

Tel: 4731225620

\begin{abstract}
The diversity of diatoms in the hot springs of the Comanjilla geothermal zone in northern Guanajuato, Mexico was studied. Hot springs are extreme ecosystems that, despite having high temperatures, constitute an environment for many thermophilic microorganisms (bacteria, cyanobacteria, and diatoms). The thermal water studied is classified as hyperthermal water $\left(45^{\circ} \mathrm{C}\right.$ to $100^{\circ} \mathrm{C}$ ), of deep origin, and with low mineralization, are of type sulfuric sodium chloride, since the dissolved content of hydrogen sulfide $\left(\mathrm{H}_{2} \mathrm{~S}\right)$ is found in concentrations higher than $1 \mathrm{mg} / \mathrm{L}$, and its smell is similar to the one of rotten eggs, presents a pH of 7.6 to 9.1 that represents neutrophilic to alkaliphilic environments, with a variable electrical conductivity (EC) $(658-698 \mu \mathrm{s} / \mathrm{cm})$ and total dissolved solids (TDS) (314-24 ppm). In the same way, these hot springs present microbial mats that consist of several stratified layers of green and orange color of $100 \mathrm{~cm}^{2}$, each one, which are dominated by specific types of microorganisms such as bacteria, cyanobacteria, but mainly diatoms, the latter were studied applying the scanning electron microscope and the optical microscope. The morphological characteristics observed in the optical microscope and in the scanning electron microscopy indicate the presence of diatoms of the Bacillariophyceae class, represented by Sellaphora disjuncta (55\%), Achnanthes brevipes var. intermedia (45\%). This diatom present in thermophilic microbial mats in the sulphurous geothermal zone of Comanjilla represents: a) the first report of said microorganisms in the study area and Mexico; b) an ecosystem of great interest from the biotechnological and industrial point of view; c) an important taxon in terms of diversity and technology; d) an applications in biofuels, environmental monitoring, wastewater treatment, manufacture of fertilizers, production of secondary metabolites, medical compounds, energy sources and food industry and within nanotechnology. It is important to mention that the physical and chemical characteristics of thermal water such as temperature, $\mathrm{pH}$, dissolved solids, electrical conductivity, hardness, alkalinity and silica concentrations, were the major environmental factors influencing the distribution of diatoms in sulphurous hot springs.
\end{abstract}

(c)2021 Puy-Alquiza et al. Published by Avanti Publishers. This is an open access article licensed under the terms of the Creative Commons Attribution Non-Commercial License which permits unrestricted, non-commercial use, distribution and reproduction in any medium, provided the work is properly cited. (http://creativecommons.org/licenses/by-nc/4.0/) 


\section{Introduction}

Diatoms in thermophilic microbial mats are interesting study organisms for basic as well as for biotechnology application. In recent years, diatoms have been studied not only from the academic point of view but also within industrial and biotechnological applications. Proof of this are the applications that have been given to them within the industrial and commercial sector, such as carbon neutral, synthesis of fuels, pharmaceuticals, health foods, biomolecules, materials relevant to nanotechnology, and bioremediatory of contaminated water, biomonitoring, paleoecology, and forensics analyzes, which can be combined in the near future to make diatoms a lucrative source of novel substances with widespread relevance [1, 2]. Diatoms are unicellular, eukaryotic and photosynthetic organisms are unique microscopic algae that contain silica and have different geometric shapes. It is known that they form microbial mats and are produced in wet places where photosynthesis is possible. These photosynthetically active organisms are responsible for $20-25 \%$ of total terrestrial primary production, and approximately $40 \%$ of annual marine biomass production [3], making them the most dominant group of organisms sequestering carbon from the atmosphere. These microorganisms live generally in marine, freshwater and terrestrial ecosystems but there are few studies that describe them in an ecosystem of hot springs $[4,5,6]$. There are few species of heterotrophic diatoms that survive in dark conditions, some live as endosymbionts in some organisms or non-invasively on the body surface of organisms, for example, it is the foraminifera that host endosymbiotic algae such as diatoms and chlorophytes. So, each species of diatoms exhibits a specific environmental tolerance, forming sets of species corresponding to the condition of the habitat [7]. It is important to mention that in Mexico there are no studies related to the subject and the information about thermophilic diatoms found in hot springs is null, so the data obtained in said research will provide knowledge about the physical-chemical composition of thermal water and its importance in microbial diversity. In addition, the data obtained will be compared with studies carried out in other countries. Diatoms studied live in thermal springs usually located along fault lines where groundwater can be stored and heated up to reach a certain depth and then emerge in the form of hot water. The heated water contains a wide range of dissolved minerals ( $F e, M n, ~ M g$, $\mathrm{Ca}, \mathrm{Na})$ and traces of gases $\left(\mathrm{CO}_{2}, \mathrm{H}_{2}, \mathrm{H}_{2} \mathrm{~S}, \mathrm{CO}\right)[8,9]$. The chemistry of thermal waters varies a lot and depends mainly on the properties of the source rock. Due to the temperature gradients present in the thermal water flow channel, different microbial communities (halophiles, thermophiles, barophiles, pscryophiles and acidophiles) can be established in these channels [10]. Microbial diversity in microbial mats of sulphurous hot springs is a major resource for biotechnological products and processes because of the role of microbes in nutrient cycling, the production of large amounts of bio-based chemicals, polymeric substances, energy sources and biofuels, environmental detoxification, metabolic abilities in pharmaceuticals and industrial processes and act as a major resource for agricultural, industrial, and medicinal applications [11, 12]. The thermophiles microorganisms represent the most promising option as a source of extremozymes with extreme stability able to withstand drastic process condition [13]. The presence of thermal springs in the state of Guanajuato has been recognized by local inhabitants since before the arrival of the Spaniards. In the state of Guanajuato have been reported several thermal sources potentially exploitable from the energy point of view as medicinal and recreational. The presence to the outside of this type of waters is related to the existence of faults that connect the deep spring of thermal water, with the surface, which allows the ascent of the waters. The thermal springs are numerous (173) and are frequently distributed in several places in the state of Guanajuato, as a result of the tectonic activity and the phenomena subsequent to the intense volcanism of which its territory has been subject, since it belongs to the provinces physiographic of the Mesa del Centro, Sierra Madre Oriental and Eje Neovolcánico. The diatoms of the Guanajuato hot springs have been studied to obtain information on the diversity of genera and species that inhabit these waters and develop an understanding of the ecology and life cycle of diatoms in order to be able to use them for various commercial and industrial purposes. The main objective of this study was to describe the taxonomy of the community of diatoms that inhabit thermophilic microbial mats present in sulfurous hot springs, at the same time to analyze those physicochemical factors that affect their abundance, and to evaluate the biotechnological potential that they may have the diatoms described in this work. For this last objective, specialized databases on the subject were used. The knowledge obtained from this research will be used to create an inventory of diatom species in hot springs and compare them with those diatoms reported in different ecosystems (marine, freshwater and terrestrial), in the same way it will be the basis of a reference resource for the detection and application of these thermal water diatoms in industrial and biotechnological processes. 


\section{Description of the study area}

Comanjilla is located 32 kilometers from the city of Guanajuato, Mexico. It is accessed by the federal highway number 45 that joins the cities of Silao and Leon with a branch of $10 \mathrm{~km}$, at the height of the village of the Sauces that goes to the Aquatic Park of Comanjilla (Figure 1). Due to the healing properties of its thermal waters, the Aquatic Park of Comanjilla was well known and appreciated. This thermal source corresponds to the Comanjilla geothermic zone of where 25 hydrothermal springs are located, some as hotbeds with deposition of sulfur and mineral salts with surface temperatures between $45^{\circ}$ and $92^{\circ} \mathrm{C}$, distributed in an area of $1.2 \mathrm{~km} 2$. The thermal source was studied by evaluating source emergency temperature, appearance, smell, taste, mineralization, hardness, turbidity, dissolved solids and cation concentrations $\left(\mathrm{Na}, \mathrm{Mg}, \mathrm{Mo}, \mathrm{Ca}^{+2}, \mathrm{~K}^{+}, \mathrm{S}, \mathrm{Al}^{+3}\right)$, anions $\left(\mathrm{H}_{2} \mathrm{~S}, \mathrm{SO}_{4}, \mathrm{Cl}\right)$, oxides $\left(\mathrm{SiO}_{2}, \mathrm{Al}_{2} \mathrm{O}_{3}, \mathrm{MgO}, \mathrm{K} 2 \mathrm{O}, \mathrm{P}_{2} \mathrm{O}_{5}, \mathrm{SO}_{3}, \mathrm{Fe}_{2} \mathrm{O}_{3}\right)$, and trace elements ( $\mathrm{Cu}, \mathrm{Zr}, \mathrm{Si}, \mathrm{Ar}$, and $\mathrm{Rh}$ ), allowing them to be classified, in terms of their chemical composition and thermalism as hyperthermal waters $\left(45^{\circ} \mathrm{C}\right.$ to $\left.100^{\circ} \mathrm{C}\right)$ with a global chemical tendency of the ions towards an $\mathrm{H}_{2} \mathrm{~S}-\mathrm{Na}$ type behavior (sodium sulphides), of deep origin and of low mineralization, observing a high content of silica and low in Calcium and Magnesium. From the geological point of view, the hot springs are in a depression filled with Cenozoic sediments, delimited, and cut by faults. The thermal waters are related to volcanic units of intermediate composition, basalts, rhyolites, conglomerate, and sandstones.

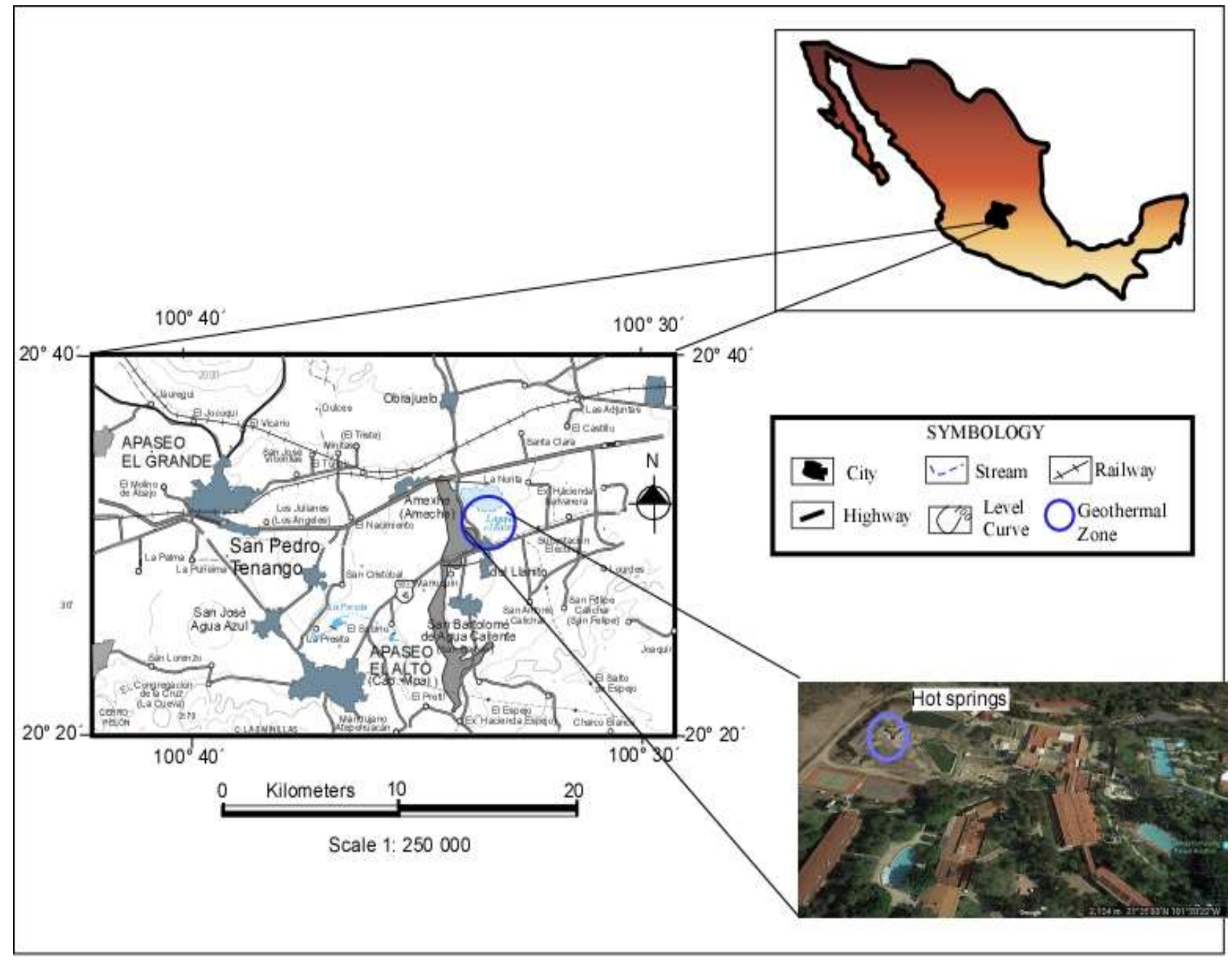

Figure 1: Location of area of study. 


\section{Methodology}

\subsection{Thermophilic Microbial Mats Sampling and Characterization}

Seven hot springs in the Comanjilla geothermal zone in the state of Guanajuato possessing differing physical and chemical characteristics were chosen for this study. The samples (M1, M2, M3, M4, and M5) are collected from five hot springs out of the seven recorded in the study area during the months of December 2017 to April 2018 (Figure 2). The samples were selected considering the alignment of hot springs to fault systems, which correspond to two families. The first family is characterized by a system NE-SW which cuts the second NW-SE fault system. These fault systems contribute to the different physical and chemical characteristics of the hot springs. The samples (M1, M2, and M3) belong to the NE-SW fault system, and the microbial mats have a brown coloration, while the samples (M4, and M5) belong to the NW-SE system and the coloration of the microbial mats is green. Samples were collected aseptically from one thermophilic microbial mats of hot springs Comanjilla in different thermo flask and processed immediately in the laboratory. Three replicates were taken for the sample from the same spot of the same location. For the sampling, preservation, and handling of the samples, the Official Mexican NOM [14], was followed. The samples taken were placed in coolers with cooling bags or ice bags closed for transport to the laboratory, at a temperature between $4^{\circ} \mathrm{C}$ and $10^{\circ} \mathrm{C}$, taking care not to freeze the samples.
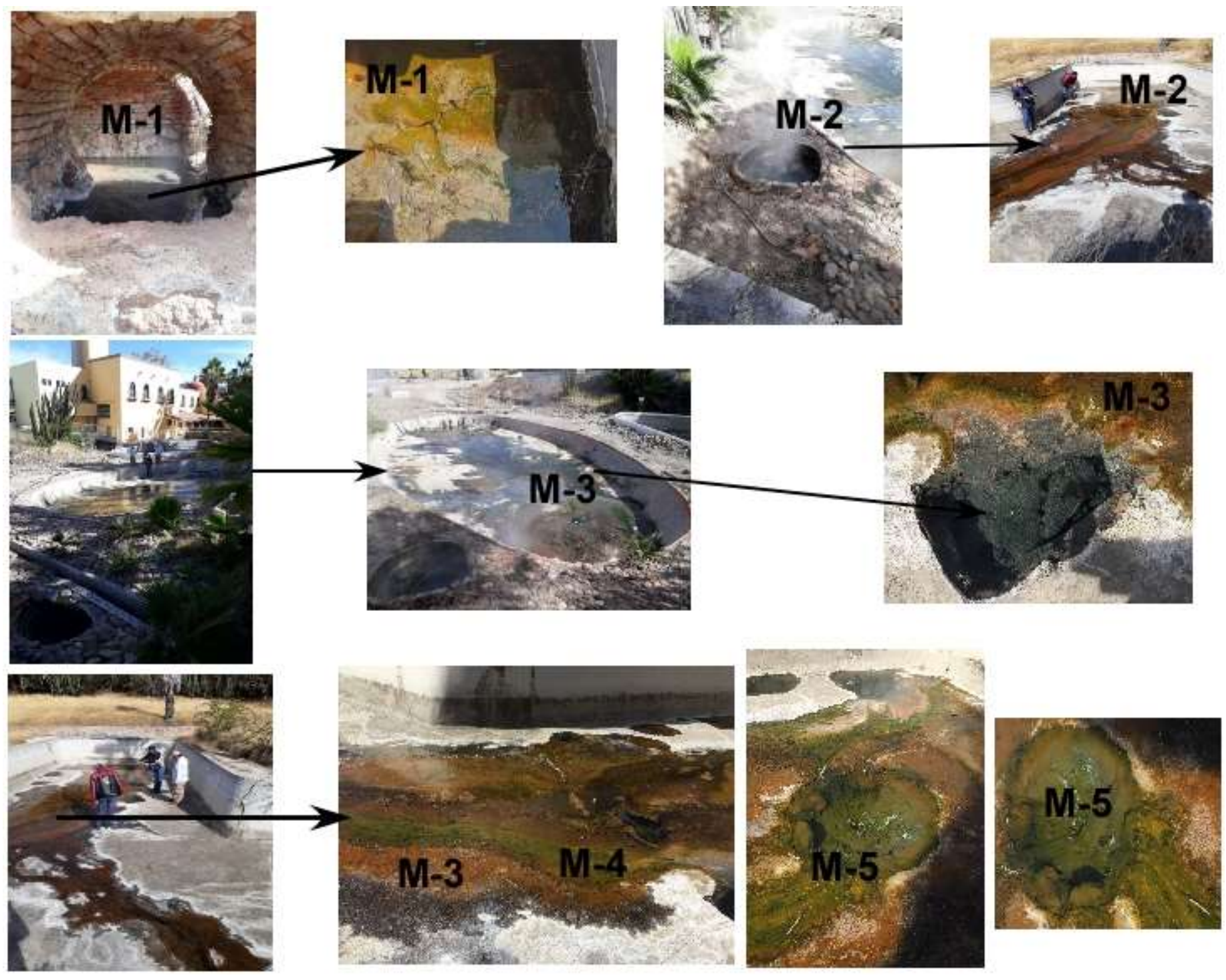

Figure 2: Photographs of five sulphurous hot springs in Comanjilla geothermic zone. M1, M2, M3, brown microbial mats; M4, M5 green microbial mats. 


\subsection{Physical Characteristics of Water in the Thermophilic Microbial Mats}

Physical properties such as: a) temperature, b) $\mathrm{pH}$ c) electrical conductivity (EC), d) total dissolved solids (TDS) and e) water hardness of bacterial carpet was measured in situ using thermometer mercury with precision of $1^{\circ} \mathrm{C}$. The $\mathrm{pH}$ was determined with a Corning potentiometer model $610 \mathrm{~A}$. The electrical conductivity (EC) was measured with a Conductivity Meter 850037 SPER SCIENTIFIC. The total dissolved solids (TDS) were measured with a TDS PURIKOR PK-TDS3 and the hardness in the water was calculated based on the content of calcium and magnesium salts.

\subsection{Chemical Characteristics of Water in the Thermophilic Microbial Mats}

For the analysis of cation, anions and metals concentrations, the X-ray fluorescence (XRF) technique was used. Samples are analyzed with a Rigaku NEX CG X-ray fluorescence spectrometer using energy dispersion (EDXRF). The spectrometer has a Pd anode X-ray tube, a maximum power of $50 \mathrm{~W}$ with a maximum voltage of $50 \mathrm{kV}-2 \mathrm{~mA}$, and in an atmosphere of it. The analysis was carried out in the LICAMM UG laboratory of the Department of Mines, Metallurgy, and Geology of the Guanajuato University.

\subsection{Identified Microorganisms in Thermophilic Microbial Mats}

\subsubsection{Diatoms Observation to the Scanning Electron Microscopy (SEM), Optical Microscope and Classification}

The morphological aspects of the diatom were investigated by (SEM) observation with gold coating and with an optical microscope equipped with a digital camera (Olympus BX40). The SEM instrument (JEOL, JSM- 6010 PLUS/LA) was operated at $15 \mathrm{kV}$ in a low vacuum, while the energy dispersion scanner spectrometer (EDS), attached to the SEM, and was used for semi-quantitative chemical analysis. The SEM-EDS analyses were carried out in the laboratory LICAMM of the Guanajuato University. For its observation the protocol of [15] was used, describing it below: 1. The sample was filtered with a filter that does not dissolve with organic solvent. 2. The filters were placed in suitable containers for drying at critical points. 3. Fixed with a $2.5 \%$ glutaraldehyde solution in $0.1 \mathrm{M}$ phosphate buffer prepared with filtered seawater. 4. To remove the salts, the samples were transferred to decreasing concentrations of seawater. 5. After fixing it was dehydrated in series of growing ethanol. 6 . Finally the sample was dried in the desiccator to critical point. The guide of [16], was used for the generic allocation of diatoms.

\section{Results}

\subsection{Characterization of the Samples}

The Prospecting of five hot springs in Comanjilla between December 2017 and April 2018 was carried out. Thermal waters represent moderate to high thermophilic $\left(45^{\circ} \mathrm{C}\right.$ to $\left.100^{\circ} \mathrm{C}\right)$ and neutrophil to alkalophilic $(\mathrm{pH}$ 7.69.1), transparent color, rotten egg odor, sulfurous taste, turbidity (60-70 NTU), environments with variable electrical conductivity (658 $\mu \mathrm{S} / \mathrm{cm}$ to $704 \mu \mathrm{S} / \mathrm{cm}$ ) and total dissolved solids (314 ppm-569 ppm), (Table 1). The five hot springs are aligned transversely to the fault systems. Five samples (M1, M2, M3, M4, and M5) were obtained from the thermal sources of the geothermal zone of Comanjilla limited by two fault systems. Sample M1, $\mathrm{M} 2$, and $\mathrm{M} 3$ were obtained from the brown microbial mats, which has a $\mathrm{pH}$ 9.1, with a temperature that varies from $64^{\circ} \mathrm{C}$ to $92^{\circ} \mathrm{C}$, classifying these waters as hyperthermal. Associated with the NE-SW fault system. Its $\mathrm{pH}$ indicates that it is slightly alkaline water. The hardness range in french degrees of this type of water is $32^{\circ} \mathrm{f}$ to $42^{\circ} \mathrm{f}$, which indicates hard water. The electrical conductivity varies from $658 \mu \mathrm{S} / \mathrm{cm}$ to $704 \mu \mathrm{S} / \mathrm{cm}$, which indicates poor brackish water (Table 1). According to its mineralogical composition, the type of water M1, M2, and M3 (Slightly alkaline), it is classified as chlorinated sulphurous water, since the content of hydrogen sulfide solution $\left(\mathrm{H}_{2} \mathrm{~S}\right)$ is found in concentrations higher than $1 \mathrm{mg} / \mathrm{L}$, and its smell is similar to rotten eggs. Similarly, they have low mineralization and low calcium (Ca) and Magnesium (Mg) and high silica (Si), Aluminum (Al), and chlorine (Cl) content, which indicates a deep origin (Table 2). The sample M4 and M5 were obtained from the green microbial

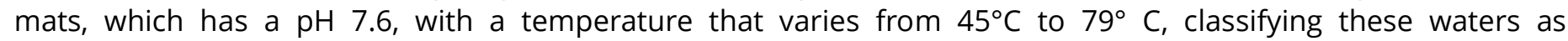
hyperthermal. Associated with the NW-SE fault system. Its $\mathrm{pH}$ indicates that it is neutral water. The hardness range in french degrees of this type of water is $32^{\circ} \mathrm{f}$ to $42^{\circ} \mathrm{f}$, which indicates hard water. The electrical conductivity is $690 \mu \mathrm{S} / \mathrm{cm}$ to $698 \mu \mathrm{S} / \mathrm{cm}$, which indicates poor brackish water (Table 1). According to its mineralogical 
composition, the type of water M4, and M5 (neutral) is classified as chlorinated sulphurous water, since the dissolved content of hydrogen sulfide $\left(\mathrm{H}_{2} \mathrm{~S}\right)$ is found in concentrations higher than $1 \mathrm{mg} / \mathrm{L}$, and its smell is similar to of rotten eggs. Similarly, they have low mineralization and low calcium (Ca) and Magnesium (Mg) and high silica (Si), Aluminum (Al), and chlorine (Cl) content, which indicates a deep origin (Table 2). Chemically both samples have similar values in $\mathrm{Cu}, \mathrm{S}, \mathrm{Cl}$, being different in values of $\mathrm{Al}, \mathrm{Ca}, \mathrm{Mg}, \mathrm{Zr}$, Mo, Si, $\mathrm{K}, \mathrm{Ar}$, and $\mathrm{Rh}$ (Table 2). Regarding the values of oxides, $\mathrm{M} 1, \mathrm{M} 2$, and $\mathrm{M} 3$ show higher concentrations in $\mathrm{MgO}, \mathrm{K}_{2} \mathrm{O}, \mathrm{CaO}$, and $\mathrm{Fe}_{2} \mathrm{O}_{3}$ compared with the $\mathrm{M} 4$ and M5. However, $\mathrm{M} 4$, and $\mathrm{M} 5$ show higher concentrations in $\mathrm{SiO}_{2}, \mathrm{Al}_{2} \mathrm{O}_{3}, \mathrm{P}_{2} \mathrm{O}_{5}, \mathrm{H}_{2} \mathrm{~S}, \mathrm{SO}_{3}, \mathrm{SO}_{4}$ ( $\mathrm{Table} 2$ ).

Table 1: Organoleptic and physic characteristics of thermal water springs, of the Comanjilla geothermal zone.

\begin{tabular}{|c|c|c|c|c|c|c|c|c|c|c|c|c|}
\hline $\begin{array}{c}\text { Thermal } \\
\text { Water Spring }\end{array}$ & $\begin{array}{l}\text { Failure } \\
\text { System }\end{array}$ & $\begin{array}{l}\text { Type of } \\
\text { Water }\end{array}$ & Color & Odor & Taste & $\begin{array}{l}\text { Turbidity } \\
\text { (NTU) }\end{array}$ & $\mathrm{pH}$ & $\mathrm{T}^{\circ} \mathrm{C}$ & $\begin{array}{c}\text { SDT } \\
(\mathrm{ppm})\end{array}$ & $\begin{array}{c}E C \\
(\mu S / \mathrm{cm})\end{array}$ & ${ }^{\circ} \mathrm{f}$ & Hardness \\
\hline M1 & NE-SW & slightly alkaline & Transparent & Rotten egg & Sulphurous & 70 & 9.1 & 78 & 314 & 658 & $32-42$ & hard \\
\hline M2 & NE-SW & slightly alkaline & Transparent & Rotten egg & Sulphurous & 70 & 9.1 & 64 & 340 & 704 & $32-42$ & hard \\
\hline M3 & NE-SW & slightly alkaline & Transparent & Rotten egg & Sulphurous & 70 & 9.1 & 92 & 569 & 683 & $32-42$ & hard \\
\hline M4 & NW-SE & neutral & Transparent & Rotten egg & Sulphurous & 60 & 7.6 & 79 & 324 & 698 & $32-42$ & hard \\
\hline M5 & NW-SE & neutral & Transparent & Rotten egg & Sulphurous & 60 & 7.6 & 45 & 328 & 690 & $32-42$ & hard \\
\hline
\end{tabular}

Table 2: XRF analysis of thermal water springs, of the Comanjilla geothermal zone. ND no detected.

\begin{tabular}{|c|c|c|c|c|c|}
\hline $\begin{array}{l}\text { ELEMENT } \\
(\mathrm{ppm})\end{array}$ & $\begin{array}{c}\text { M1 } \\
\text { Slightly Alkaline }\end{array}$ & $\begin{array}{c}\text { M2 } \\
\text { Slightly Alkaline }\end{array}$ & $\begin{array}{c}\text { M3 } \\
\text { Slightly Alkaline }\end{array}$ & $\begin{array}{c}\text { M4 } \\
\text { Neutral }\end{array}$ & $\begin{array}{c}\text { M5 } \\
\text { Neutral }\end{array}$ \\
\hline \multicolumn{6}{|l|}{ CATIONS } \\
\hline $\mathrm{Na}$ & ND & ND & ND & ND & ND \\
\hline $\mathrm{Mg}$ & 112 & 110 & 111 & ND & ND \\
\hline Mo & 9.14 & 9.1 & 9.14 & 5.08 & 5 \\
\hline $\mathrm{Ca}^{2+}$ & 22.1 & 21.9 & 22 & 26.2 & 26 \\
\hline $\mathrm{K}^{+}$ & 18.1 & 17.9 & 18 & 30.8 & 30 \\
\hline $\mathrm{S}$ & 24.2 & 24.1 & 24 & 25.6 & 25.5 \\
\hline $\mathrm{Al}^{3+}$ & 238 & 235 & 236 & 247 & 246 \\
\hline \multicolumn{6}{|l|}{ ANIONS } \\
\hline $\mathrm{H}_{2} \mathrm{~S}^{-}$ & 27 & 25 & 26 & 55 & 54 \\
\hline $\mathrm{SO}_{4}=$ & 76 & 74 & 75 & 154 & 153 \\
\hline $\mathrm{Cl}^{--}$ & 19.4 & 19.3 & 19.2 & 17.8 & 17.5 \\
\hline \multicolumn{6}{|c|}{ TRACE ELEMENTS } \\
\hline $\mathrm{Cu}$ & 2.9 & 2.8 & 2.7 & 2.9 & 2.8 \\
\hline $\mathrm{Zr}$ & 244 & 243 & 245 & 312 & 311 \\
\hline $\mathrm{Si}$ & 307 & 305 & 306 & 261 & 260 \\
\hline $\operatorname{Ar}$ & 253 & 251 & 252 & 132 & 131 \\
\hline $\mathrm{Rh}$ & ND & ND & ND & 892 & 891 \\
\hline \multicolumn{6}{|c|}{ OXIDES (mass \%) } \\
\hline $\mathrm{SiO}_{2}$ & 48.6 & 48.4 & 48.5 & 49.4 & 49.3 \\
\hline $\mathrm{TiO} 2$ & ND & ND & ND & ND & ND \\
\hline $\mathrm{Al}_{2} \mathrm{O}_{3}$ & 23.2 & 23.1 & 23.1 & 29.4 & 29.3 \\
\hline $\mathrm{MnO}$ & ND & ND & ND & ND & ND \\
\hline $\mathrm{Na} 2 \mathrm{O}$ & ND & ND & ND & ND & ND \\
\hline $\mathrm{MgO}$ & 8.85 & 8.84 & 8.83 & 1.93 & 1.92 \\
\hline $\mathrm{K}_{2} \mathrm{O}$ & 4.31 & 4.30 & 4.30 & 0.018 & 0.017 \\
\hline $\mathrm{CaO}$ & 4.06 & 4.05 & 4.04 & ND & ND \\
\hline $\mathrm{P}_{2} \mathrm{O}_{5}$ & 1.12 & 1.10 & 1.11 & 2.56 & 2.55 \\
\hline $\mathrm{SO}_{3}$ & 9.26 & 9.22 & 9.25 & 16.7 & 16.6 \\
\hline $\mathrm{Fe}_{2} \mathrm{O}_{3}$ & 0.55 & 0.53 & 0.54 & ND & ND \\
\hline
\end{tabular}




\subsection{Identified Diatoms in Thermophilic Microbial Mats with Scanning Electron Microscopy (SEM) and Optical Microscope}

A total of seven species of diatom were determined in thermophilic microbial mats present in sulphurous hot springs of geothermal zone of Comanjilla (Figures 3, 4, 5. 6, and 7), predominantly Bacillariophyceae class. The name Bacillariophyceae has been used in several ways: to refer to all diatoms or to refer to the raphe-bearing pennate diatom or to refer to all pennate diatoms. In our case, we mean all the diatoms pennate.
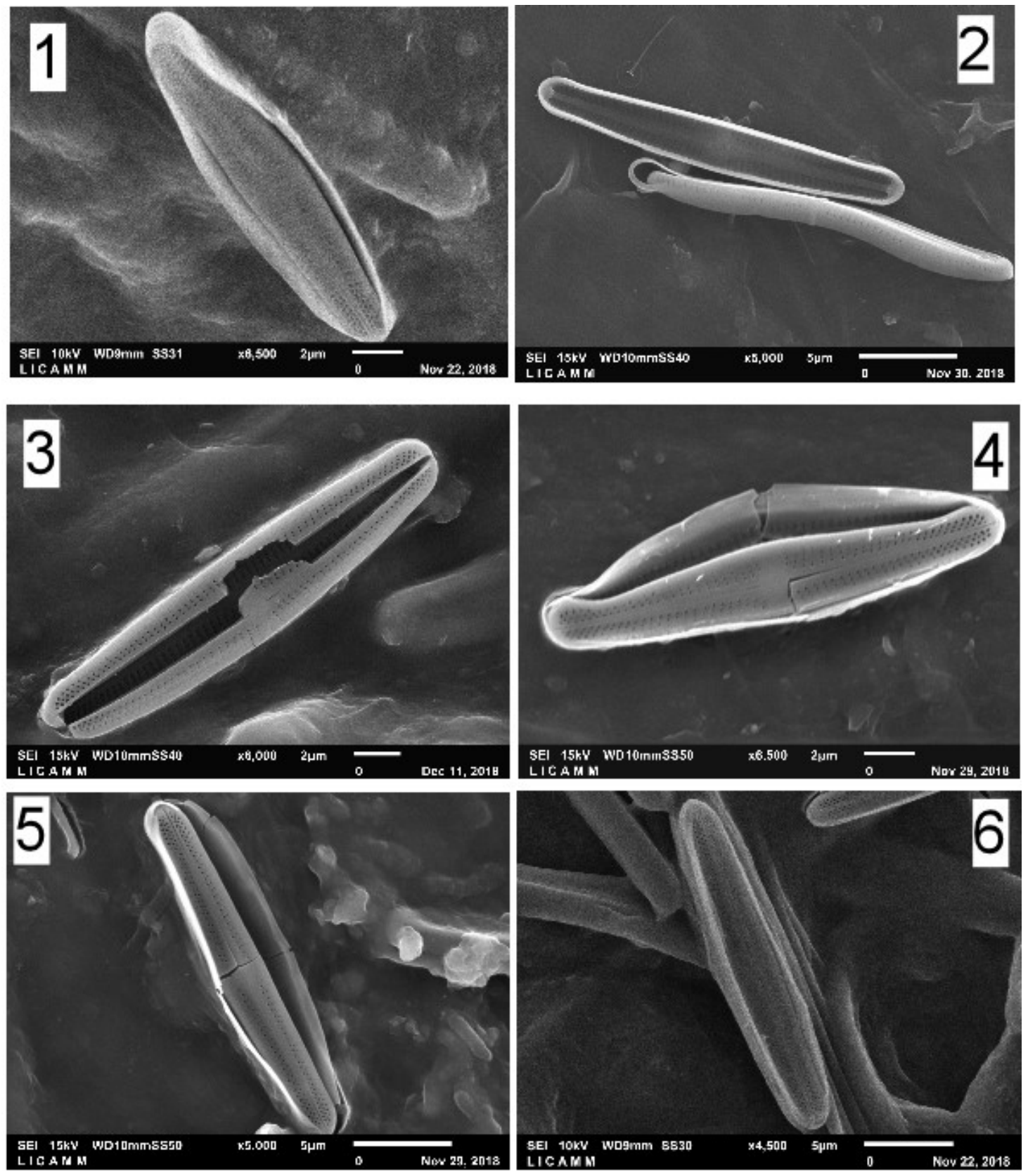

Figure 3: SEMs of Achnanthes brevipes var. intermedia. (1-5). External views of raphe valves. (6). Internal view of RV with valvocopula, showing the copilae with two rows.

\subsubsection{Identified Diatoms in Thermophilic Microbial Mats with Scanning Electron Microscopy (SEM)}

Achnanthes brevipes var. intermedia (Kützing) Cleve [17], were determined in thermophilic microbial mats present in sulphurous hot springs of the geothermal zone of Comanjilla (Figure 2), belongs to the 
Bacillariophyceae class. The Bacillariophyceae class is unicellular algae characterized by a silica outer shell or frustule [18]. They comprise one of the most abundant algal groups globally and are important in benthic and planktonic algal communities in freshwater, marine, and terrestrial habitats. A. brrevipes var intermedia belongs to the genus Achnanthes [19, 20]. Her basionym is Achnanthes intermedia Kützing 1833, and her synonym is Achnanthes intermedia Kützing 1833; Achnanthes subsessilis Kützing 1833; Achnanthidium brevipes var. intermedia '(Kützing) Cleve' VanLandingham 1967. Her Parent is Achnanthes brevipes C. Agardh, 1824. The general environment is marine, freshwater, and brackish. In the study area, these diatoms coexist with the genus Bacillus represented by Brevibacillus agri and Paenibacillus sp., to temperatures of $70^{\circ} \mathrm{C}$ and $92^{\circ} \mathrm{C}$ in sulphurous hot spring.
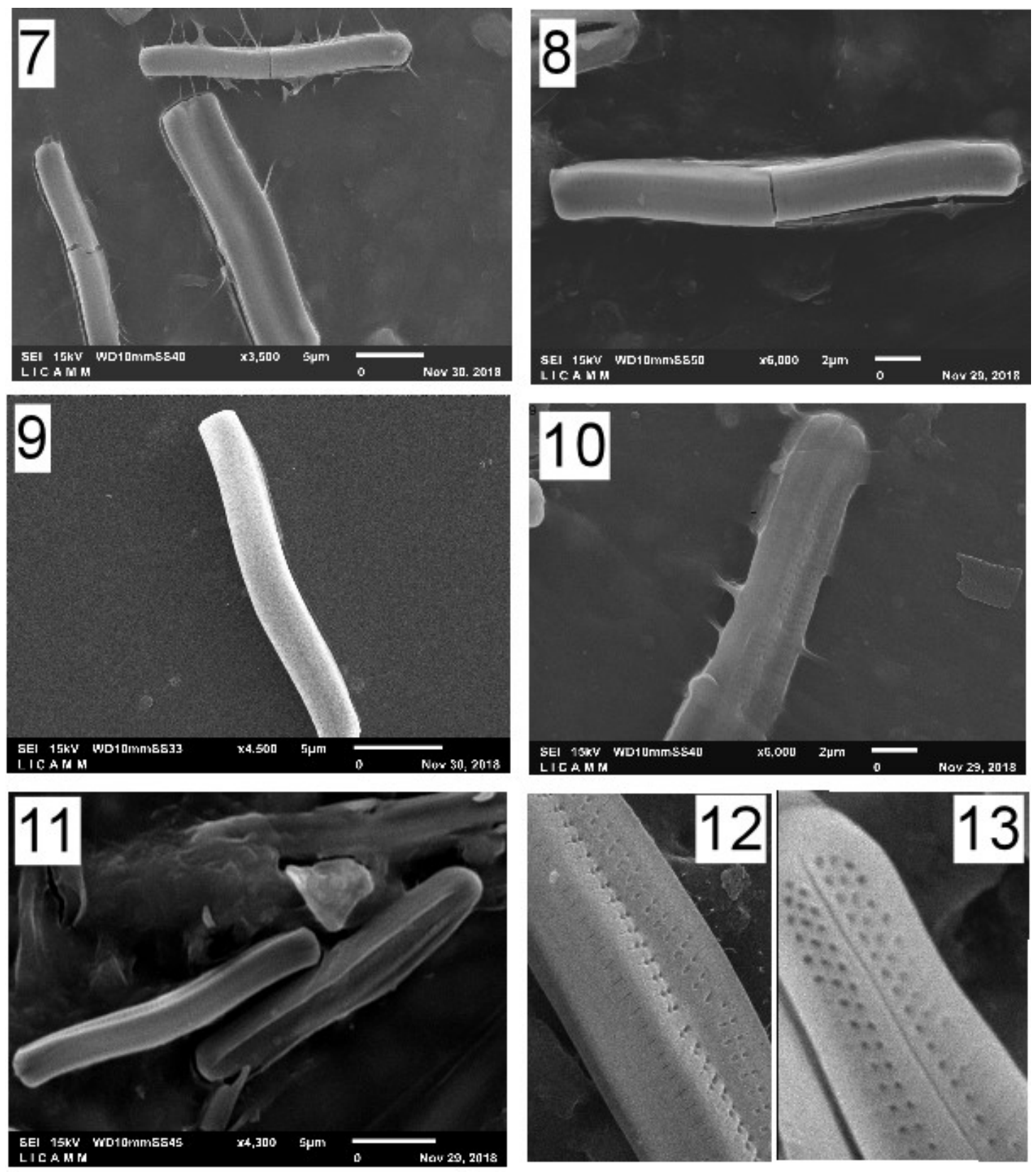

Figure 4: SEMs of Achnanthes brevipes var. intermedia. (7-11). Views of a girdle view. (12-13). Terminal fissure, curving in opposite direction to central raphe ending.

\subsubsection{Description Scanning Electron Microscopy (Fig 3, 4, 5, 6)}

Raphe valve (Fig. 3): Raphe valve with fascia. The valves are shallow and arched with a narrow, eccentric sternum. The size of the valves is $20 \mu \mathrm{m}$ of long and $5 \mu \mathrm{m}$ of width, linear-lanceolate or linear, elliptical to elliptical, 
wedge-shaped, rounded at the apices, often slightly concave in the middle. The central area is quite narrow, reaching the edges forming a transverse fascia. Internal view of RV with valvocopula, showing the copulae with two rows, and its pars interior extending inside the valve.

Girdle view (Fig. 4): The valve is slightly curved geniculately, with a convex ARV and a concave RV. Frustule usually consists of RV, ARV, and three or four copulae. Arcuate frustule forming a "V". Cíngulo made up of a reduced number of copulae. All copulae, including valvocopula, are open bands with the opening of the band alternately and connecting each other. The terminal fissures are deflected in the opposite direction to the central pores. The striae are uniseriate, with a radial arrangement Striae uniseriate, composed of almost rounded areolae with slightly recessed foramina, occluded by cribra with rounded perforations

Valve external (Fig. 5): The areolae are usually round, often tending towards the square, slightly sunk below the basal siliceous layer in external view.
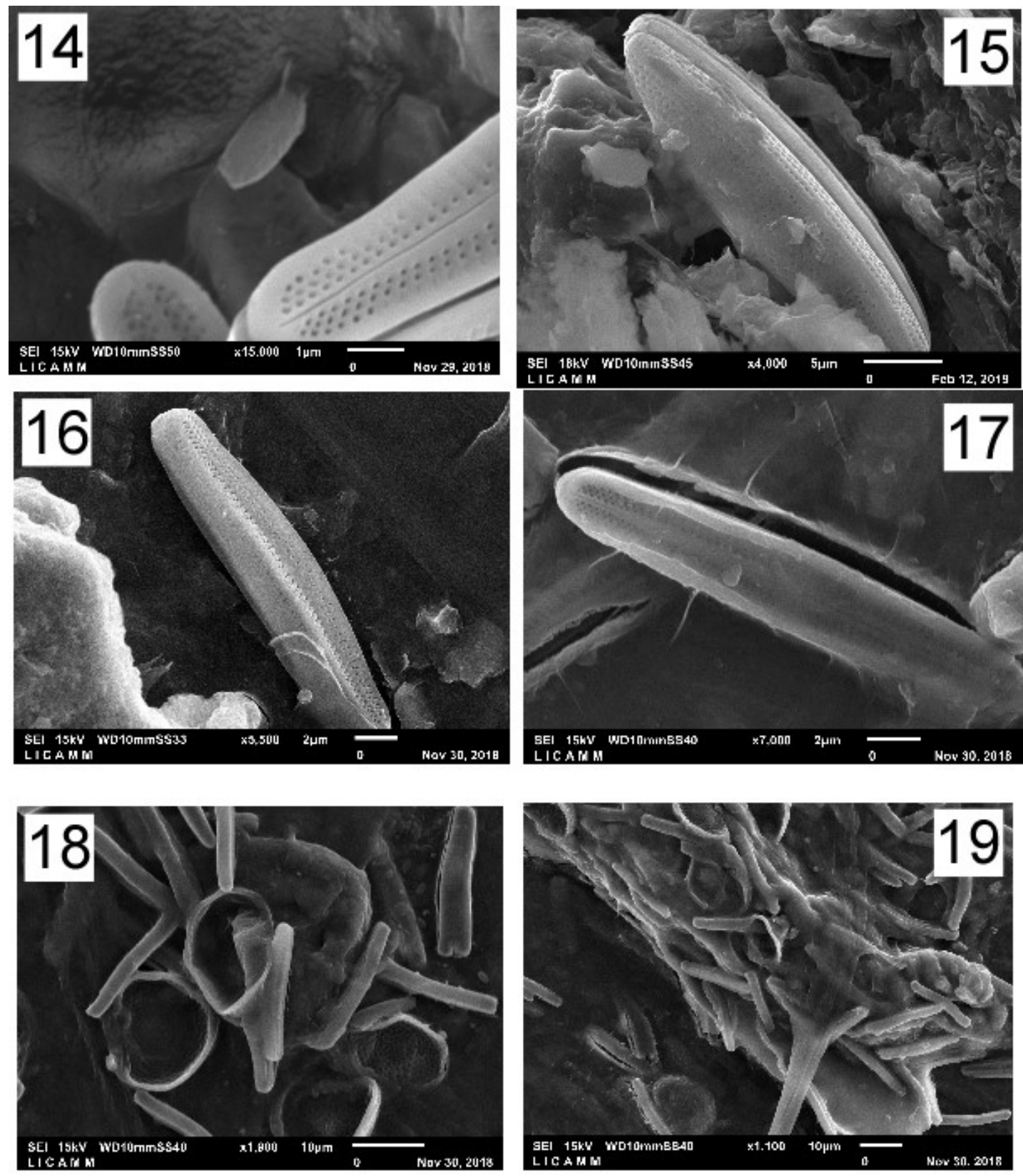

Figure 5: SEMs of Achnanthes brevipes var. intermedia. (14-17). External view of an entire raphe valves. (18-19). Achnanthes brevipes var. intermedia in thermophilic microbial mats. 
Microbial mats (Fig. 6): Achnanthes brevipes var. intermedia (Kützing) Cleve, coexist with the genus Bacillus represented by Brevibacillus agri and Paenibacillus sp., these thermophilic bacteria are of great interest due to their biotechnological importance as a source of thermostable enzymes and industrial products [21, 22].
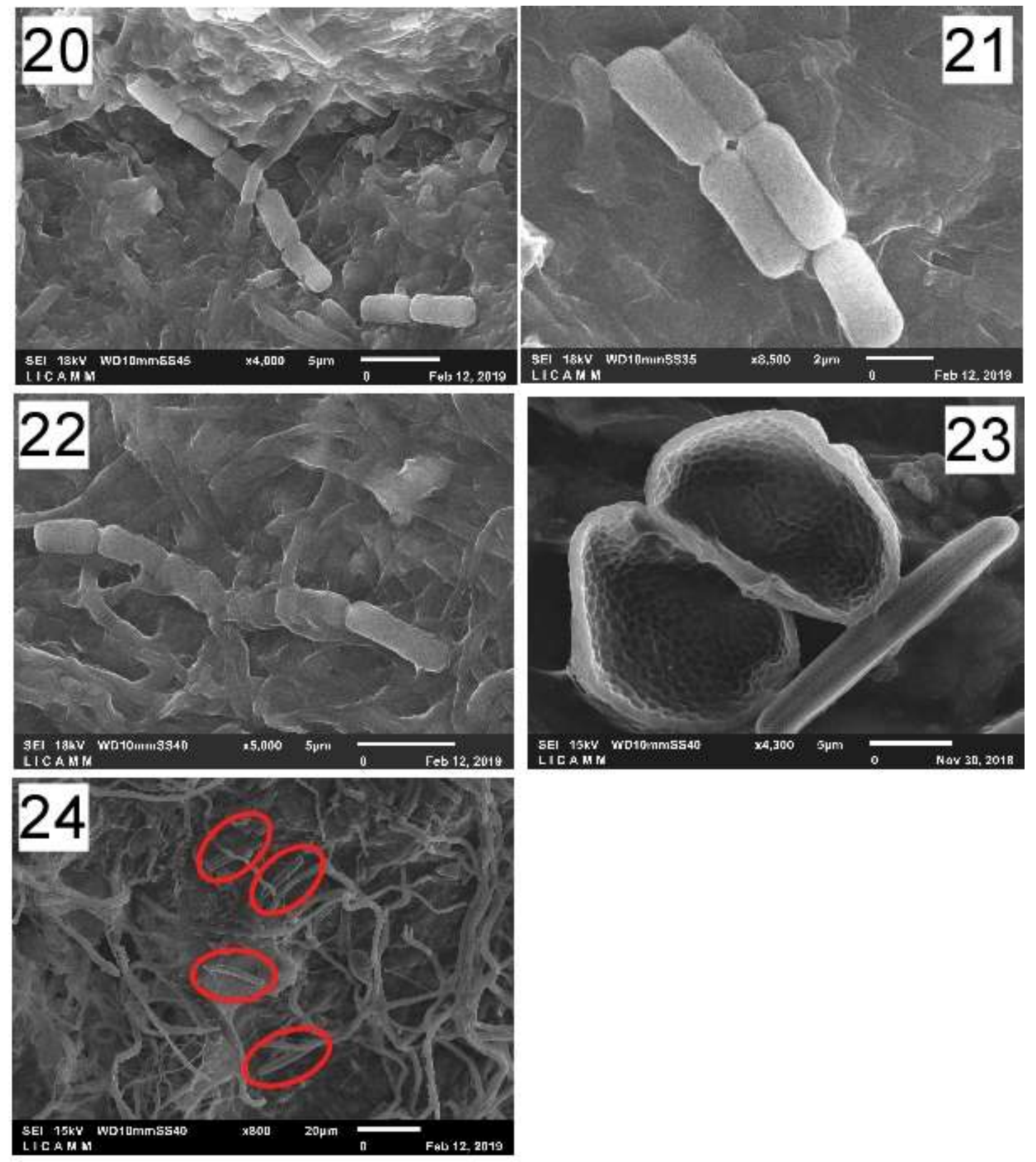

Figure 6: (20-22). SEMs of genus Bacillus represented by Brevibacillus agri and Paenibacillus sp. (23-24). Achnanthes brevipes var. intermedia, coexist with the genus Bacillus represented Brevibacillus agri, and Paenibacillus sp. In thermophilic microbial mats present in sulphurous hot springs.

\subsubsection{Identified Diatoms in Thermophilic Microbial Mats with Optical Microscope (Fig.7)}

Diatoms of the Bacillariophyceae class, represented by the Achnanthales, and Sellaphora orders, have elongate cells, shaped like boats, rods, spicules or bananas and it is sometimes stated that this, rather than the organization of the valve pattern, is the essential feature of the group. Achnanthes brevipes var. intermedia, in the optical microscope the cell is attached to the substrate: either via the raphe directly with the concave shell, or by means of a jelly stem. The second shell has no raphe. The cells have one or two H-shaped plastids. Some brackish water species have many lenticular plastids (Figure 7a). Sellaphora disjuncta, in the optical microscope the axial area is straight; the raphe is filiform (Figure $\mathbf{7 b}$ ). 

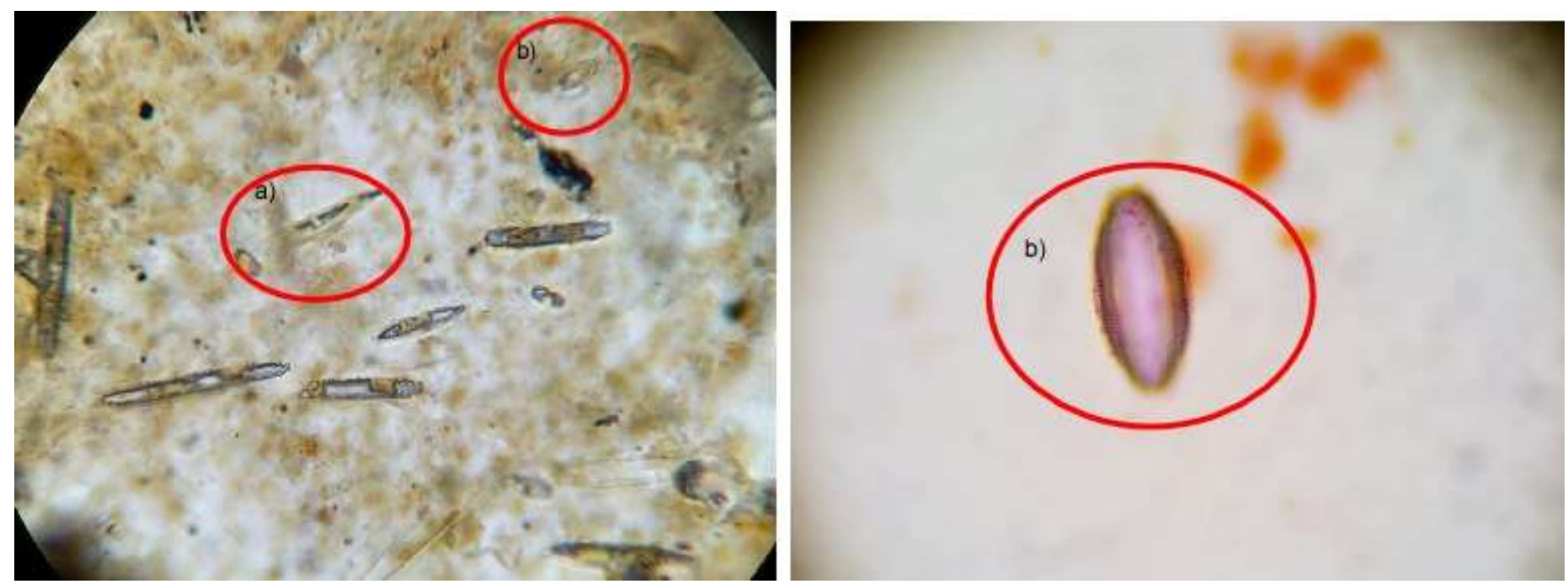

Figure 7: Photograph of diatoms in optical microscope in hot springs of the Comanjilla geothermal zone; (a) Achnanthes brevipes var. intermedia; (b) Sellaphora disjuncta (Hust.) G.G. Mann 1989.

\subsection{Ecology and Distribution}

The genus Achnanthes have been described in marine, fresh- and brackish waters [23]. According to [24], Achnanthes brevipes var. intermedia, are widely distributed and lives in waters of lower salt concentration. [25], mentioned that this species has a cosmopolitan distribution along with lowland areas even in estuaries.

\section{Discussion}

This is the first report of diatoms in thermophilic microbial mats that carpet hot springs in Mexico, where thermophilic bacteria as Brevibacillus agri and Paenibacillus sp, living in association with the diatoms of the Bacillariophyceae class represented by the genus Achnanthales, and Sellaphora. The results indicated that with the increase in the temperature of the water in the tanks above $90^{\circ} \mathrm{C}$, the number of diatom species is impoverished, as is the case of the sample M1, M2, and M3. The diatom species recorded in the sample M1, M2, and M3 have a little abundance of the species $A$. brevipes var intermedia, probably due to the conditions of $\mathrm{pH}$, slightly alkaline water, temperature, low concentrations in $\mathrm{Ca}, \mathrm{K}, \mathrm{H}_{2} \mathrm{~S}$, and $\mathrm{SO}_{4}$, higher concentrations in $\mathrm{Mg}, \mathrm{Mo}, \mathrm{MgO}, \mathrm{K} 2 \mathrm{O}, \mathrm{CaO}$ and $\mathrm{Fe}_{2} \mathrm{O}_{3}$, and absence of $\mathrm{NaCl}$. While $\mathrm{M} 4$ and $\mathrm{M} 5$ show a greater abundance of the species A. brevipes var intermedia due to the temperature, $\mathrm{pH}$, neutral water, absence of $\mathrm{NaCl}, \mathrm{Mg}$, and to the concentrations of $\mathrm{H}_{2} \mathrm{~S}_{2} \mathrm{SO}_{4}$, $\mathrm{Ca}, \mathrm{K}, \mathrm{SiO}_{2}, \mathrm{Al}_{2} \mathrm{O}_{3}, \mathrm{P}_{2} \mathrm{O}_{5}$ and $\mathrm{SO}_{3}$ compared to $\mathrm{M} 1, \mathrm{M} 2$, and $\mathrm{M}$. This indicates that $\mathrm{M} 1, \mathrm{M} 2, \mathrm{M} 3, \mathrm{M} 4$, and $\mathrm{M}$, although they correspond to the same geothermal zone, have physical and chemical characteristics that differentiate them. These differences are due to the movement of hydrothermal fluids throughout the fault systems, which cause mineralogical changes due to the introduction of certain chemical elements from the rocks. Likewise, it is important to mention that the NE-SW fault system is younger and is the one that controls the thermal springs of $\mathrm{pH}$ 9.1, while the NW-SE fault system that is older and controls the thermal springs of $\mathrm{pH} 7.6$. The increase in silica together with the $\mathrm{pH}$, temperature, and type of water were important factors for the distribution and diversity of diatoms, example of the diatoms reported in Thailand [26]. The diatoms absorb the surrounding silicon at low concentration $(<1 \mu \mathrm{M})$ and are actively transported through the membranes, such as silicic acid, then the insoluble silicon product for insertion into the mobile walls, this mechanism allows its silica biocaps (frustules) are used as nanomaterials $[15,27]$. The $\mathrm{SiO}_{2}$ content varies with the individual species and with the environmental conditions. The variables such as $\mathrm{pH}$, electrical conductivity, hardness, alkalinity, temperature, total dissolved solids, and chemical composition are involved in the relationship and abundance of species [26] since diatoms responded better to changes in the physicochemical environment [28, 29], describes the environmental variables involved in the appearance of diatoms in an estuary. In this article, they report that the environmental factors for the Achnanthes brevipes are the electrical conductivity (100) and turbidity (61). In the 
geothermal zone of Comanjilla, this species presents similar values to those reported by [29]. Electrical conductivity $(E C)$ is known to be an important factor for determining the composition of the epilithic diatom community [30]. However, some species remain at elevated temperatures and actively develop and even to form masses as Sellaphora disjuncta, so the temperature becomes an important factor. All taxa have a $\mathrm{pH}$ of neutral waters to some alkalines. Achnanthes brevipes var. intermedia to have a wide salt tolerance [31, 32]. Achnanthes brevipes var intermedia has been described by [33] in hypersaline waters, where this species presents double frustule an adjustment to hypersalinity. The measured values of Rhodium and Argon are possibly controlled by structural geology, namely the presence of previous fault systems, and by the lithology of the leached host rocks. Diatoms (Bacillariophyceae) are frequently a ubiquitous, highly successful, and distinctive group of single-celled algae, with the presence of siliceous cell walls, called frustules. Similarly, it is the richest in diatom species, representing great ecological, biotechnological, and primary production importance [3]. Diatoms contribute significantly to the productivity of many ecosystems, often forming the basis of aquatic food chains and ecological indicators [34], they are also used in biological monitoring as it responds quickly to environmental changes and provides early indications of the impacts of pollution and habitat restoration and as paleo-ecological significance $[35,30]$. They have been extensively used as indicators of environmental change: eutrophication, acidification, salinification, sea-level change, and land-use change, [36]. In recent years, diatoms have been studied for their great potential in chemical devices, solar cell batteries, and electroluminescence devices [37]. Similarly, during the last years have been studied for bio-applications, the immobilization of biomolecules, the detection of gases, and biomasses [38]. Today, the major emphasis is focused on their application in nanotechnology and biotechnology including nanofabrication techniques, chemo and biosensing, particle sorting, control of particles in micro- and nano fluidics and also on their use in analyzing ecological problems; such as climate change, acidification, and eutrophication of aqueous ecosystems, biomineralization, synthesis of biomaterial, and waste degradation, [39]. Achnanthes brevipes C. Agardh, parent of Achanathes brevipes var intermedia (Kützing) Cleve, has been studied by [40], where they selected eight examples of diatoms in different Egyptian habitats and environments: Aulacoseira granulata (Ehrenberg) Simonsen, Actinocyclus octonarius Ehrenberg, Cyclotella meneghiniana Kützing, Pleurosira laevis (Ehrenberg) Compére, Synedra ulna (Nitzspes) Agardh, Nitzschia amphibia Grunow. Nitzschia palea (Kützing) W. Smith, to study in detail the ultra-structures of their frustules, the result was that it is possible to obtain mesoporous macroparticles and silica microparticles from the species. Based on this, Achnanthes brevipes var intermedia (Kützing) Cleve, represents a potential within biotechnological applications for obtaining porous materials (Table 3). All these applications are referred to diatoms that inhabit marine ecosystems, rivers, estuaries, soils, with few studies made in thermal waters. Based on this, in this research work, we report diatom species that live together with bacteria thermophilic in an ecosystem whose temperature exceeds $90^{\circ} \mathrm{C}$. Opening a great opportunity in the applications and uses of these diatoms in this new little-explored ecosystem.

\section{Conclusion}

The diatom species described in this work live in environments at $\mathrm{pH} 7.6-9.1$ in thermophilic microbial mats derived from sulphurous hot springs from $45^{\circ} \mathrm{C}$ to $100{ }^{\circ} \mathrm{C}$. The type of water is slightly alkaline to neutral. According to (Kroger \& Poulsen, 2008) the $\mathrm{pH}$ influences in the structure of diatom communities, in diversity and in total biomass produced. The physical characteristics $\mathrm{pH}$, temperature, turbidity, and chemical composition of water were significant factors affecting the relative abundance of Achnanthes brevipes var intermedia species. It is important to highlight the lack of sodium as an element in the samples, so the concentration of $\mathrm{NaCl}$ salts is not an indicative element for the distribution of diatoms in the studied hot springs, in the same way, the electrical conductivity and total dissolved solids are not shows as a key element for the composition of diatoms since the values obtained do not present significant variations. The diversity of thermophilic microorganisms (diatoms) found in the microbial mats of hot springs of the geothermal zone of Comanjilla: 1) can be further exploited for the large-scale benefit of humanity; 2) diatoms of the Bacillariophyceae class, represents a new scenario for biotechnological applications, especially in industrial processes; 3) the study of diatoms as a functional unit will help to better understand how these complex and integrated communities adapt to life around the thermal waters, where factors such as $\mathrm{pH}$, electrical conductivity, hardness, alkalinity, temperature, chemical composition influences the relationship and abundance of these organisms; 4) diatoms are important taxa not only in terms of diversity and ecology but also due to their applications in environmental monitoring, nanotechnology, biofuels, medicine, agriculture, and food industry; 5) diatoms are considered as important elements for the synthesis of 
Table 3: Diatom applications taking into account the database of other countries in biosynthesis, biodegradation, bioremediation, biomineralization, biosensor, biodiesel, biomedical, bio nutrition, and biotechnological.

\begin{tabular}{|c|c|c|c|c|c|c|c|c|c|c|c|}
\hline Diatom Species & 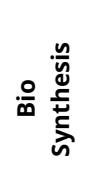 & 음 & 음 & & 임 & $\stackrel{\bar{\Phi}}{\bar{\Phi}}$ & 음 & 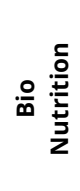 & 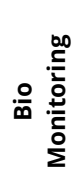 & 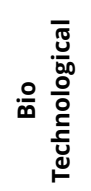 & References \\
\hline Achnanthes longipes & $\mathrm{x}$ & & & & & & $\mathrm{x}$ & $\mathrm{x}$ & & & {$[41,42]$} \\
\hline Achnanthes oblongella Oestrup & & $x$ & & & & & & & & & [43] \\
\hline Achnanthes brevipes Agardh & & & & & & & & & & $\mathrm{x}$ & [40] \\
\hline Aulacoseira granulata & & & & & & & & & & $x$ & [40] \\
\hline Amphora coffeaeformis & & $\mathrm{x}$ & & & & & $\mathrm{x}$ & $\mathrm{x}$ & & & {$[42,44]$} \\
\hline Cylindrotheca fusiformis & & & & & & & $x$ & & & & [2] \\
\hline Cyclotella sp. & & & & & $x$ & & & & & & [45] \\
\hline Cyclotella cryptica & & & & & & $x$ & $x$ & & $\mathrm{x}$ & & {$[2,46,47]$} \\
\hline Cyclotella meneghiniana & $\mathrm{x}$ & & & $\mathrm{x}$ & & & & & & $\mathrm{x}$ & {$[40,48]$} \\
\hline Cylindrotheca fusiformis & & & & & & & & & $\mathrm{x}$ & & [46] \\
\hline Cylindrotheca closterium & & $\mathrm{x}$ & & & & & & & & & [49] \\
\hline Cymbella cistula & $\mathrm{x}$ & & & & & & & & & & [41] \\
\hline Cocconeis placentula Ehr. & & $x$ & & & & & & & & & [43] \\
\hline Coscinodiscus concinnus & & & & & $\mathrm{x}$ & & & & & & [50] \\
\hline Coscinodiscus wailesii & & & & & $\mathrm{x}$ & & & & & & {$[50,51]$} \\
\hline Coscinodiscus argus & & & & & $\mathrm{x}$ & & & & & & [49] \\
\hline Chaetoceros sp. & & & & & & & & $\mathrm{x}$ & & & [42] \\
\hline Chaetoceros cryptica & $\mathrm{x}$ & & & & & & & & & & [43] \\
\hline Chaetoceros muelleri & & & & & & & & $x$ & & & [52] \\
\hline $\begin{array}{l}\text { Chaetoceros muelleri } \\
\text { var. subsalsum }\end{array}$ & & & & & & $x$ & & & & & [53] \\
\hline Cheaters calcitran & & & & & & & & & & $\mathrm{x}$ & [64] \\
\hline Chaetoceros gracilis & & & & & & $x$ & & $x$ & & & {$[52,55]$} \\
\hline Diademis gallica & $x$ & & & & & & & & & & [42] \\
\hline Ditylum birghtwellii & & & & & $\mathrm{x}$ & & & & & & [56] \\
\hline Fragilaria capucina Desm & & $\mathrm{x}$ & & & & & & & & & [43] \\
\hline Halamphora coffeaeformis & & & & & & $\mathrm{x}$ & & & & & [57] \\
\hline Haslea ostrearia & $x$ & & & & & & & & & & [43] \\
\hline Isochrysis galbana & & & & & & & & $x$ & & & [58] \\
\hline Melosira nummuloides & & & & $\mathrm{x}$ & & & & & & & [43] \\
\hline Navicula sp. & & & & & & & $\mathrm{x}$ & $\mathrm{x}$ & & $\mathrm{x}$ & [42] \\
\hline Navicula atomus & $\mathrm{x}$ & & & & & & & & & & [42] \\
\hline
\end{tabular}


(Table 3 contd....)

\begin{tabular}{|c|c|c|c|c|c|c|c|c|c|c|c|}
\hline Diatom Species & 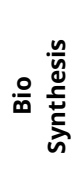 & 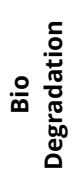 & 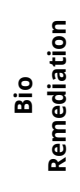 & 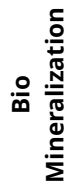 & 음 & 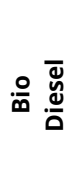 & $\stackrel{\overline{\bar{J}}}{\frac{\bar{U}}{\pi}}$ & 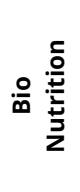 & 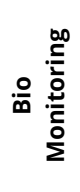 & 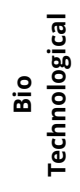 & References \\
\hline Navicula cincta & & & & & & $x$ & & & & & {$[59,60]$} \\
\hline Navicula saprophilia & & & & & & & $x$ & & & & [2] \\
\hline Navicula minima & $x$ & & & $x$ & & & & & & & [61] \\
\hline Nitzschia sp. & $x$ & $x$ & $x$ & & & & $x$ & $\mathrm{x}$ & & & {$[42,62,63]$} \\
\hline Nitzschia closterium & & & & & & $x$ & & & & & [55] \\
\hline Nitzschia soratensis & & & & & $x$ & & & & & & [49] \\
\hline Nitzschia laevis & & & & & & & $x$ & & & $x$ & [65] \\
\hline Nitzschia obtusa & $\mathrm{x}$ & & & $\mathrm{x}$ & & & & & & & [61] \\
\hline Nitzschia palea & & & & & & & & & & $\mathrm{x}$ & [40] \\
\hline Nitzschia navisvaringica & & & & & & & & & & $x$ & [15] \\
\hline Nitzschia amphibia & & & & & & & & & & $x$ & [40] \\
\hline Odontella aurita & & & & & & & & $x$ & & & [42] \\
\hline Pavlova lutheri & & & & & & & & $x$ & & & [58] \\
\hline Phaeodactylum tricornutum & $x$ & & & & & $\mathrm{x}$ & $x$ & $x$ & $\mathrm{x}$ & $x$ & {$[2,46,42,65]$} \\
\hline Pinnularia sp. & & & & $x$ & & & & & & $\mathrm{x}$ & {$[43.66]$} \\
\hline Rhizosole $s p$ & & & & & & & $x$ & & & & [42] \\
\hline Stauroneis $s p$ & $\mathrm{x}$ & & & & & & & & & & [42] \\
\hline Skeletonema sp. & & & & & & & & $\mathrm{x}$ & & & [42] \\
\hline Skeletonema costratum & & & $\mathrm{x}$ & & & $\mathrm{x}$ & $x$ & $\mathrm{x}$ & $x$ & $\mathrm{x}$ & {$[42,46,58-60]$} \\
\hline Skeletonema marinoi & & & & & & & & & & $\mathrm{x}$ & [42] \\
\hline Stephanopyxis turris & $\mathrm{x}$ & & & & & & & & & & [67] \\
\hline Stephanodiscus hantzschii & $\mathrm{x}$ & & & $\mathrm{x}$ & & & & & & & [68] \\
\hline Thalassiosira weissflogii & & & & $\mathrm{x}$ & & & $\mathrm{x}$ & & & & [2] \\
\hline Thalassiosira pseudonana & $x$ & & & $\mathrm{x}$ & $\mathrm{x}$ & & $x$ & $x$ & $\mathrm{x}$ & $\mathrm{x}$ & {$[2,46,56,58,66]$} \\
\hline Thalassiosira Rotula & & & & & $\mathrm{x}$ & & & & & $\mathrm{x}$ & [42] \\
\hline
\end{tabular}

biomaterials, for pollution problems, to rehabilitate sites and to determine the toxicity of a place by heavy metals; 6) Achnanthes genus presents applications in biosynthesis, biodegradation, bionutrition, biomedical, and biotechnology; 7) Achnanthes brevipes var intermedia, represents a potential within of the nanotechnology applications; 8) the thermal sources represent a new scenario for the study and use of thermal diatoms as an alternate application in nanotechnology and biotechnology; 9) this information may provide important tools to explain, ecological, biotechnological, and biodiversity phenomena in the hot spring. 


\section{Acknowledgements}

We are grateful to Maytee Corona for helpful, and Jesus Rene Baez Espinosa for good technical assistance. Special thanks to the laboratory LICAMM-UG for support in the realization of the analysis of the SEM. A special thanks to Strain Biotech laboratory for the genotypic characterization and phylogenetic analysis of the samples. We would like to thank the research council of the University of Guanajuato for the financial support of this research.

\section{References}

[1] Kale A, Karthick B. The Diatoms Big Significance of Tiny Glass Houses. Resonance 2015; 919-930. https://doi.org/10.1007/s12045-0150256-6

[2] Bozarth A, Maier UG, Zauner S. Diatoms in biotechnology: modern tools and applications. Appl Microbiol Biotechnol 2009; 82: 195201. https://doi.org/10.1007/s00253-008-1804-8

[3] Field CB, Behrenfeld MJ, Randerson JT, Falkowski P. Primary production of the biosphere: integrating terrestrial and oceanic components. Sci 1998; 281: 237-240. https://doi.org/10.1126/science.281.5374.237

[4] Ghozzi K, Zemzem M, Dhiab RB, Challouf R, Yahia A, Omrane H, Ouada HB. Screening of thermophilic microalgae and cyanobacteria fromTunisian geothermal sources. J Arid Environ 2013; 97: 14-17. https://doi.org/10.1016/j.jaridenv.2013.05.004

[5] Ramachandra TV, Madhab- Mahapatra D, Karthick B, Gordon R. Milking Diatoms for Sustainable Energy: Biochemical Engineering versus Gasoline-Secreting Diatom Solar Panels. Ind. Engine. Chem Res 2009; 48(19): 8769-8788. https://doi.org/10.1021/ie900044j

[6] Kociolek JP, Blanco S, Coste M, Ector L, Liu, Y, Karthick B, Kulikovskiy M, Lundholm N, Ludwig T, Potapova M, Rimet F, Sabbe K, Sala S, Sar E, Taylor J, Van de Vijver B, Wetzel CE., Williams DM, Witkowski A, Witkowski J. Diatom Base. 2021; Accessed at http://www.diatombase.org on 2021-08-13. doi:10.14284/504

[7] Cowan DA. Enzymes from thennophilic archaebacteria: Current and future applications in biotechnology. Biochem Soc Symp 1992; 58: 149-169.

[8] Lukavsky J, Furnadzhieva S, Pilarski P. Cyanobacteria of the thermal spring at Pancharevo. Act Bot Croat 2011; 70(2): $191-208$. https://doi.org/10.2478/v10184-010-0015-4

[9] Reysenbach AL, Cady SL. Microbiology of ancient and modern hydrothermal systems. Trends Microbiol 2001; 9(2): $79-86$. doi:10.1016/s0966-842x (00)01921-1. https://doi.org/10.1016/S0966-842X(00)01921-1

[10] Singh SP. Extreme Environments and Extremophiles, in National Science Digital Library (CSIR): E- Book, Environ Microbiol CSIR India 2006; 1-35.

[11] Chen GQ, Jiang XR. Next generation industrial biotechnology based on extremophilic bacteria. Cur Opine Biotechnol 2018; 50: 94-100. https://doi.org/10.1016/j.copbio.2017.11.016

[12] Bhandiwad A, Guseva A, Lynd, L. Metabolic engineering of thermo- anaerobacterium thermosaccharolyticum for increased n-Butanol production. Adv. Microbiol 2013; 3: 46-51. https://doi.org/10.4236/aim.2013.31007

[13] Daniel R. The metagenomics of soil. Nat Rev Microbiol 2005; 3: 470-478. https://doi.org/10.1038/nrmicro1160

[14] NORMA Oficial Mexicana NOM-230-SSA1-2002. Salud ambiental. Agua para uso y consumo humano, requisitos sanitarios que se deben cumplir en los sistemas de abastecimiento públicos y privados durante el manejo del agua. Procedimientos sanitarios para el muestreo.

[15] Martin-Jézéquel V, Calu G, Candela L, Amzil Z, Jauffrais T, Séchet V, Weigel P. Effects of organic and inorganic nitrogen on the growth and production of domoic acid by Pseudo-nitzschia multiseries and P. australis (Bacillariophyceae) in Cultur Marin Drugs 2015; 13: 7067-7086. https://doi.org/10.3390/md13127055

[16] Lorenz P, Eck J. Metagenomics and industrial applications. Nat Rev Microbiol 2005; 3: 510-516. https://doi.org/10.1038/nrmicro1161

[17] Kützing FT. Die Kieselschaligen Bacillarien oder Diatomeen. pp. [i-vii], [1]- 152, pls 1-30. Nordhausen: zu finden bei W. Kohne. 1844 https://doi.org/10.5962/bhl.title.64360

[18] Round FE, Crawford RM, Mann DG. The Diatoms. Biology and Morphology of the Genera. Cambridge University Press, Cambridge 1990.

[19] Toyoda K, Cox EJ, Sims PA, Williams DM. The typification of Achnanthes Bory based on Echinella stipitate Lyngbye, with an account of the morphology and fine structure of Lyngbye's species. Diat Res 2005; 20: 375-386. https://doi.org/10.1080/0269249X.2005.9705643

[20] Novarino G. Some observations on the girdle of Achnanthes longipes. Diat Res 1992; 7: $281-292$. https://doi.org/10.1080/0269249X.1992.9705220

[21] Sharp R.J, Riley PW, White D. Heterotrophic thermophilic bacilli. In: Kristjansson, J.K. (Ed.), Thermophilic Bacteria. CRC Press, Boca Raton 1992 19-50. https://doi.org/10.1201/9781003068334-2

[22] Maugeri TL, Gugliandolo C, Caccamo D, Stackebrandt E. A polyphasic taxonomic study of thermophilic bacilli from shallow, marine vents. Syst Appl Microbiol 2001; 24: 572-587. https://doi.org/10.1078/0723-2020-00054 
[23] VanLandingham SL. Catalogue of the fossil and recent genera and species of diatoms and their synonyms. Part I. Acanthoceras through Bacillaria, Vol 1. Verlag von J Cramer, Lehre 1967.

[24] Hustedt F. Die Kieselalgen Deutschlands, Österreichs und der Schweiz. In: Kryptogamen-Flora von Deutschlands, Oesterreichs und der Schweiz (Rabenhorst L, ed). Akademische Verlagsgesellschaft m.b.h, Leipzig 1931; 609-920.

[25] Leira M, López-Rodríguez MC, Carballeira R. Epilithic diatoms (Bacillariophyceae) from running Waters in NW Iberian Peninsula (Galicia, Spain). Anal Jard Bot Madrid 2017; 74(2): e062. https://doi.org/10.3989/ajbm.2421

[26] Pumas C, Pruetiworanan S, Peerapornpisal Y. Diatom diversity in some hot springs of northern Thailand Bot 2018; 24(1): 69-86. https://doi.org/10.2478/botlit-2018-0007

[27] Knight MJ, Senior L, Nancolas B, Ratcliffe S, Curnow P. Direct evidence of the molecular basis for biological silicon transport. Nat Commun 2016; 7: 1-11. https://doi.org/10.1038/ncomms11926

[28] Leland HV, Porter SD. Distribution of benthic algae in the upper Illinois River basin in relation to geology and land use. Fresh Biol 2000; 44: 279-301. https://doi.org/10.1046/j.1365-2427.2000.00536.x

[29] Kim HK, Cho IH, Hwang EA, Kim YJ, Kim BH. Benthic Diatom Communities in Korean Estuaries: Species Appearances in Relation to Environmental Variables. Int. J Environ Res Pub Heal 2019; 16(15): 1-20. https://doi.org/10.3390/ijerph16152681

[30] Potapova M, Charles DF. Diatom metrics for monitoring eutrophication in rivers of the United States. Ecol Ind 2007; 7: 48-70. https://doi.org/10.1016/j.ecolind.2005.10.001

[31] Siqueiros-Beltrones DF. Benthic diatoms from laguna Figueroa, Baja California. Ciencias Marinas 1988; $14(2)$ : 85-112. https://doi.org/10.7773/cm.v14i2.586

[32] Jones VJ. The diversity, distribution and ecology of diatoms from Antarctic inland waters. Bio Cons 1996; 5: 1433-1449. https://doi.org/10.1007/BF00051986

[33] Round FE. Benthic Marine Diatoms. Oceanogr. Marin Biol Ann Rev 1971; 9: 83-139.

[34] Srivastava P, Verma J, Grover S, Sardar A. On the importance of diatoms as ecological indicators in river ecosystems: a review. Ind J Plant Sci 2016; 5(1): 70-86.

[35] Hassan GS. Paleoecological Significance of Diatoms in Argentinean Estuaries: what Do They Tell Us About the Environment?. Nova Sci Pub 2010; 80.

[36] Polge N, Sukatar A, Neyran Soylu E, Gönülol A. Epipelic Algal Flora in the Küçükçekmece Lagoon. Turk. J Fish Aquat Sci $2010 ; 10: 39-45$. https://doi.org/10.4194/trjfas.2010.0106

[37] Ezzati J, Dolatabadi N, De la Guardia M. Applications of diatoms and silica nanotechnology in biosensing, drug and gene delivery, and formation of complex metal nanostructures. Trend. Anal Chem 2011; 30: 1538-1548. https://doi.org/10.1016/j.trac.2011.04.015

[38] Medarevic D, Losic D, Ibric S. Diatoms - Nature materials with great potential for bioapplications. Hemijska industrija 2015; 70(00): 6969. https://doi.org/10.2298/HEMIND150708069M

[39] Dolatabadi JEN, De la Guardia M. Applications of diatoms and silica nanotechnology in biosensing, drug and gene delivery, and formation of complex metal nanostructures. Trend Anal Chem 2011; 30(9): 1538-1548. https://doi.org/10.1016/j.trac.2011.04.015

[40] Abo-Shady AM, Zalat AA, Al-Ashkar EA, Ghobara MM. Nanoporous Silica of Some Egyptian Diatom Frustules as a Promising Natural Material. J Nanosci Nanotechnol-Asia 2019; 9: 414. https://doi.org/10.2174/2210681208666180321113834

[41] Wang Y, Chen Y, Lavin C, Gretz MR. Extracellular matrix assembly in diatoms (Bacillariophyceae). iv. ultrastructure of Achnanthes longipes and Cymbella cistula as revealed by high-pressure freezing/freeze substituton and cryo-field emission scanning electron microscopy. J Phycol 2000; 36: 367-378. https://doi.org/10.1046/j.1529-8817.2000.99102.x

[42] Kuppusamy SI, Srigopalra S, Yusoff MM, Maniam GP, Govindan N, Choi KC. Potential pharmaceutical and biomedical applications of Diatoms microalgae-An overview. Indian J Geo Marine Sciences 2017; 46(04): 663-667.

[43] Maznah WOW, Mansor M. Aquatic pollution assessment based on attached diatom communities in the Pinang River Basin, Malaysia. Hydrobiol 2002; 487(1): 229-241. https://doi.org/10.1023/A:1022942200740

[44] Valiente MC, Bricheux G, Portelli C, Bohatier J. Comparative effects of the herbicides chlortoluron and mesotrione on freshwater microalgae. Environ Toxicol Chem 2012; 31: 778-786. https://doi.org/10.1002/etc.1749

[45] Gale DK, Gutu T, Jiao J, Chang CH, Rorrer GL. Photoluminescence Detection of Biomolecules by Antibody-Functionalized Diatom. Biosilica Adv Funct Mater 2009; 19: 926-933. https://doi.org/10.1002/adfm.200801137

[46] Tiwari A, Marella, TK. Potential and Application of Diatoms for Industry-Specific Wastewater Treatment. In: Gupta S., Bux F. (eds) Application of Microalgae in Wastewater Treatment. Springer, Cham 2019. https://doi.org/10.1007/978-3-030-13913-1_15

[47] Dunahay TG, Jarvis EE, Dais SS, Roessler PG. Manipulation of microalgal lipid production using genetic engineering. Appl Biochem Biotechnol 1996; 57: 223. https://doi.org/10.1007/BF02941703

[48] De Jonge MD, Holzner C, Baines SB, Twining BS, Ignatyev K, Diaz J, et al. Quantitative 3D elemental microtomography of Cyclotella meneghiniana at 400-nm resolution. PNAS, 2010; 107(36): 15676-15680. https://doi.org/10.1073/pnas.1001469107

[49] Li Y, Gao J, Meng F, Chi J. Enhanced biodegradation of phthalate acid esters in marine sediments by benthic diatom Cylindrotheca closterium. Sci Total Environ 2015; 508: 251 -257. https://doi.org/10.1016/j.scitotenv.2014.12.002

[50] De Stefano L, Rea I, Rendina I, De Stefano M, Moretti L. Lensless light focusing with the centric marine diatom Coscinodiscus walesii. Opt Express 2007; 15: 18082-18088. https://doi.org/10.1364/OE.15.018082 
[51] Lin KC, Kunduru V, Bothara M, Rege K, Prasad S, Ramakrishna BL. Biogenic nanoporous silica-based sensor for enhanced electrochemical detection of cardiovascular biomarkers proteins. Biosensors and Bioelectronics 2010; 25(10): 2336-2342. https://doi.org/10.1016/j.bios.2010.03.032

[52] Brown MR, Jeffrey SW, Volkman JK, Dunstan GA. Nutritional properties of microalgae for mariculture. Aquaculture 1997; $151: 315$-331. https://doi.org/10.1016/S0044-8486(96)01501-3

[53] Chelf P. Environmental control of lipid and biomass production in two diatom species. J Appl Phycol 1990; 2: 121-129. https://doi.org/10.1007/BF00023373

[54] Chen GQ, Jiang XR. Next generation industrial biotechnology based on extremophilic bacteria. Curr Opin Biotechnol 2018; 50: 94-100. https://doi.org/10.1016/j.copbio.2017.11.016

[55] Cheng J, Feng J, Ge T, Yang W, Zhou J, Cen K. Pyrolytic characteristics of biodiesel prepared from lipids accumulated in diatom cells with growth regulation. J Biosci Bioeng 2015; 120: 161 -166. https://doi.org/10.1016/j.jbiosc.2014.12.010

[56] Rijstenbil JW, Derksen JWM, Gerringa LJA, Poortvliet TCW. Sandee A, van den Berg M, van Drie J, Wijnholds JA. Oxidative stress induced by copper: defense and damage in the marine planktonic diatom Ditylum brightwellii, grown in continuous cultures with high and low zinc levels. Mar Biol 1994; 119: 583-590. https://doi.org/10.1007/BF00354321

[57] Martín LA, Popovich CA, Martinez AM, Damiani MC, Leonardi Pl. Oil assessment of Halamphora coffeaeformis diatom growing in a hybrid two -stage system for biodiesel production. Renew Energy 2016; 92: 127-135. https://doi.org/10.1016/j.renene.2016.01.078

[58] Hemaiswarya S, Raja R, Ravi-Kumar R, Ganesan V, Anbazhagan C. Microalgae: a sustainable source for feed in aquaculture. W.J. Microbiol Biotechnol 2011; 27(8): 1737-1746. https://doi.org/10.1007/s11274-010-0632-z

[59] Gao G, Wu M, Fu Q, Li X, Xu J. A two-stage model with nitrogen and silicon limitation enhances lipid productivity and biodiesel features of the marine bloom -forming diatom Skeletonema costatum. Bioresour Technol 2019 ; 289. https://doi.org/10.1016/j.biortech.2019.121717

[60] Popovich CA, Pistonesi M, Hegel P, Constenla D, Bielsa GB, Martín LA, et al. Unconventional alternative biofuels : Quality assessment of biodiesel and its blends from marine diatom Navicula cincta. Algal Res 2019; 39 : 101438. https://doi.org/10.1016/j.algal.2019.101438

[61] Chakraborty N, Pal R, Ramaswami A, Nayak D, Lahiri S. Diatom: A potential bio-accumulator of gold. J Radioanalyt Nuclear Chem 2006; 270(3): 645-649. https://doi.org/10.1007/s10967-006-0475-0

[62] Yamamoto T, Goto I, Kawaguchi O, Minagawa K, Ariyoshi E, Matsuda O. Phytoremediation of shallow organically enriched marine sediments using benthic microalgae. Mar Pollut Bull 2008; 57: 108-115. https://doi.org/10.1016/j.marpolbul.2007.10.006

[63] Hong YW, Yuan DX, Lin QM, Yang TL. Accumulation and biodegradation of phenanthrene and fluoranthene by the algae enriched from a mangrove aquatic ecosystem. Mar Pollut Bull 2008; 56: 1400 -1405. https://doi.org/10.1016/j.marpolbul.2008.05.003

[64] Derrien A, Coiffard LJ, Coiffard C, De Roeck-Holtzhauer Y. Free amino acid analysis of five microalgae. Journal of applied phycology 1998; 10(2): 131-134. https://doi.org/10.1023/A:1008003016458

[65] Lebeau T, Robert JM. Diatom cultivation and biotechnologically relevant products. Part II: Current and putative products. Appl Microbiol Biotechnol 2003; 60(6): 624-632. https://doi.org/10.1007/s00253-002-1177-3

[66] Jeffryes C, Campbell J, Li H, Jiao J, Rorrer G. The potential of diatom nanobiotechnology for applications in solar cells, batteries, and electroluminescent devices. Energy Environ Sci 2011; 4(10): 3930-3941. https://doi.org/10.1039/c0ee00306a

[67] Pytlik N, Kaden J, Finger M, Naumann J, Wanke S, Machill S, Brunner E. Biological synthesis of gold nanoparticles by the diatom Stephanopyxis turris and in vivo SERS analyses. Algal Res 2017; 28: 9-15. https://doi.org/10.1016/j.algal.2017.10.004

[68] Jaccard T, Ariztegui D, Wilkinson KJ. Incorporation of zinc into the frustule of the freshwater diatom Stephanodiscus hantzschii. Chem Geol 2009; 265(3-4): 381-386. https://doi.org/10.1016/j.chemgeo.2009.04.016 